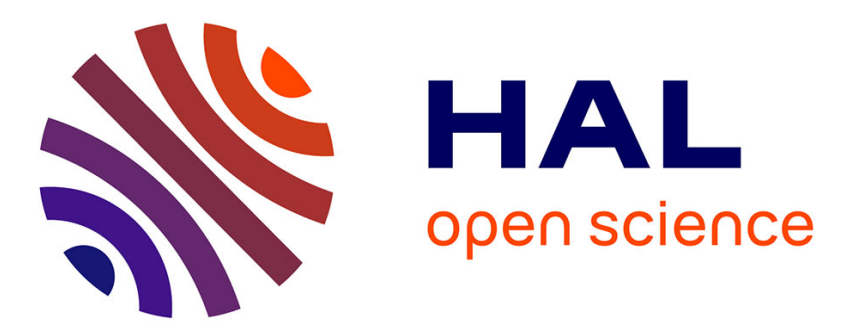

\title{
From the communist point of view: Cultural hegemony and folkloric manipulation in Albanian studies under socialism
}

Enika Abazi, Albert Doja

\section{- To cite this version:}

Enika Abazi, Albert Doja. From the communist point of view: Cultural hegemony and folkloric manipulation in Albanian studies under socialism. Communist and Post-Communist Studies, 2016, 49 (2), pp.163-178. 10.1016/j.postcomstud.2016.04.002 . halshs-01309745

\section{HAL Id: halshs-01309745 \\ https://shs.hal.science/halshs-01309745}

Submitted on 23 Jun 2016

HAL is a multi-disciplinary open access archive for the deposit and dissemination of scientific research documents, whether they are published or not. The documents may come from teaching and research institutions in France or abroad, or from public or private research centers.
L'archive ouverte pluridisciplinaire HAL, est destinée au dépôt et à la diffusion de documents scientifiques de niveau recherche, publiés ou non, émanant des établissements d'enseignement et de recherche français ou étrangers, des laboratoires publics ou privés. 


\title{
From the communist point of view: Cultural hegemony and folkloric manipulation in Albanian studies under socialism
}

\author{
Enika Abazi ${ }^{a}$, Albert Doja ${ }^{\text {b,* }}$ \\ ${ }^{a}$ Paris Peace Research Institute, France \\ ${ }^{\mathrm{b}}$ University of Lille, France
}

\section{A R T I C L E I N F O}

\section{Article history:}

Available online 28 April 2016

\section{Keywords:}

People's culture

Folklore

Folklorism

Socialism

Communist regime

Albania

Southeast Europe

\begin{abstract}
A B S T R A C T
In the standard folkloric and ethnographic tradition of Albanian studies, various efforts to seize an authentic, traditional and popular culture, supposed to have really functioned in a society of official ideology, were devoted primordially to a catalogue of descriptivist and empiricist research, which only served to confirm the ultimate goal of constructing a primarily essentialized national specificity and a particularly antiquated view of national culture. Whereas the long-term continuities in the Albanian studies of people's culture (kultura popullore), which pre-dated and out-lived socialism, together with the ambiguous relationship to anthropology are emphasized elsewhere, in this paper we look more closely at the limited changes and innovations that occurred in the decades of communist regime in Albania. The aim is to uncover how the traditional ethnographic-folkloric studies of people's culture, marked by intellectual isolation and stigmatized by association with moralist and nationalist ideologies, were mobilized to service the shifting ideological needs and state policies towards the cultural hegemony of the communist regime.
\end{abstract}

๑) 2016 The Regents of the University of California. Published by Elsevier Ltd. All rights reserved.

\section{Introduction}

This article stems from a question on cultural hegemonies in spaces of diversity, formulated with an invitation to give a presentation at a conference organized by the Graduate School for East and Southeast European Studies in Regensburg (Germany) in May 2015. ${ }^{1}$ Some earlier articles focused more specifically on the folkloric archaism of the studies of "people's culture" (kultura popullore) in Albania (Doja, 2015), largely inspired by the nationalist Kulturpolitik and colonialist Ostpolitik of the German-Austrian tradition of Volkskunde (Doja, 2014a, b). In this article, the primary aim is to explore the ways in which cultural knowledge was created, and then used and misused under Socialism in Albania. It is our contention to argue that the methodological approach adopted by these studies, namely the folklorist, empiricist and historicist character facilitated the subversion of scholarship in this area into a political instrument of communist propaganda, cultural hegemony and state control.

In recent years an increasing number of works are dealing critically with related issues (Schwandner-Sievers, 2009; Hysa, 2010; Voell, 2011), including our own earlier (Doja, 1998) and more recent reflections (Abazi, 2010, 2011; Doja, 2013a, 2014a,

\footnotetext{
* Corresponding author.

${ }^{1}$ An earlier partial version of this article was also presented at the Conference on "The Rise of Anthropology in the Margins of Europe, 1945-1991", Max Planck Institute for Social Anthropology, Halle/Saale (Germany), 9-10 March 2011 (Video at http://youtu.be/NeQ1ECIQSRc).
} 
b, 2015). ${ }^{2}$ The kind of critical elaborations taken up in this article are now current in anthropology and social science more generally, in cultural studies, in post-colonial theory, and more recently in post-socialist studies. They might be very attractive, particularly given the ordinarily pedestrian proceedings of much Albanian studies. Yet the danger of arbitrarily attributing to former writers motivations that stem indirectly from contemporary concerns is not to be minimized. The knowledge production must therefore be carefully contextualized and approached in detail with both a critical and an insightful eye, without falling into the trap of a simple ideological critique. We stick to a review of the communist period of Albanian folkloric-ethnographic studies, commenting on what most scholars actually achieved at these times, and highlighting how the reading of their products shed light on the fact that knowledge and politics are deeply intertwined.

From the communist point of view, people's culture had to turn into an ideal projection of the fixed idea of the communists as builders of a new emancipated world, a New Man and a new culture. The transformation mechanisms touched all sides of the cultural process, including the meaning of people's culture and the code that served to catalogue, analyze and interpret cultural production. To analyze this process we adopt a political anthropological perspective. In this sense, our approach is at once comparative, holistic and relativistic. In practical terms, we consider the contributions and research publications that unfolded in the cultural and political space of communist Albania in parallel with all cultural activities and institutional arrangements that constituted the discourse of the communist regime, including the interventions of state and party organizations in issues of people's culture that determined its new meaning, its new role and its new social status.

The arguments that itemize examples of how the manipulation of people's culture either takes place or is disputed, their critical assessment and the insights discussed here are firmly grounded in several sources from the bulk of publications in the genre of folkloric-ethnographic studies of people's culture produced during the socialist period in Albania, including the contributions to Etnografia Shqiptare (Yearbook of Albanian Ethnography), Çështje të Folklorit Shqiptar (Issues in Albanian Folklore) and Kultura Popullore (Journal of People's Culture), or to the national conferences on Albanian studies (1962, 1968, 1969), social issues (1969), folklore festivals $(1973,1978)$ and ethnographic studies $(1976,1983)$. Other primary sources include some Enver Hoxha's speeches and other Party documents that typically address many issues closely related to the scholarly production that is the subject of this study, including the education of youth with communist morality, the formation and consolidation of socialist mentality, socio-economic consequences of socialist transformations, changes in the socio-class structure of society, the diminution of rural and urban differences, the development of socialist relations within the family, the emancipation of women, the socialist ways of life, and so on.

On the role of ideology, the arguments of this study are better and more clearly substantiated by the programmatic articles in the Party periodical press, especially in the collection of Rruga e Partisë (Party Way), a monthly journal published by the Institute of Marxist-Leninist Studies and controlled by the Party Central Committee. The choice is determined by the very task of this "political and theoretical organ" of the Party press that was to lead the political and ideological education of state officials, party ideologues and research scholars, with contributions that reflected the real problems as perceived and intended by the ideological apparatus of the communist regime. Continuously, from its inception in 1953 to its termination in 1989, in every issue of the journal, there is no contribution without direct or indirect reference to important features of cultural research policy throughout the evolving conditions of the building of socialism. A careful examination of these contributions can highlight the real weight of the research strategy of the Albanian communist model, as they also show the evolvement of a political and moral mystification in a form contradicted by the sociocultural situation in Albania.

In addition, the claims are substantiated by what could be termed the methodological opportunity of a primary lived experience that has made it possible to monitor more closely the substance and meaning of the scholarly discourse on people's culture and the politics of knowledge in Albania more generally. One of the authors is a member of the young generation of scholars who used to work under political pressure as a junior researcher at the Institute of People's Culture, where he gained a primary lived experience on the politics of knowledge under the communist regime, and eventually rebelled against it. Another author is a member of the new generation of political scientists who in the past have suffered the most from the cultural reference of belonging both to the old class of landowners in South Albania and to the alienated class of deep-rooted intellectuals hostile to the communist regime. After a consequent full training and long experience working in modern anthropology and political science respectively, building on earlier critical examinations of the folkloric archaism of people's culture studies in Albania from "an insider/outsider perspective" (Doja, 2015), and the materialist historicist descriptivism in Albanian studies from the perspective of modern analytical and political approaches (Abazi, 2010, 2011), an additional experiential intersubjectivity is gained from a personal experience to substantiate the political dimension of the problems raised.

Finally, at this time we shall be retrospective, concerned more with taking stock rather than with proposing the kinds of new directions that must be addressed at another time. In the first section, we provide a general characterization of Albanian native studies glorifying and essentializing one's own people's culture. In three following sections, we distinguish three main phases in the course of socialist changes, which are aimed to show the linkage between evolving projects of people's culture engineering and the increase in power of the Hoxha regime in Albania. Until about the mid-1950s, the Sovietization and deSovietization of communist ideas of internationalism moved away everything that could suspect a whiff of reactionary

\footnotetext{
2 Some useful considerations are more specifically intended as a "practical necessity" how to use this body of works, more often for the completion of graduate requirements, and hence more closely related to works on specific topics, such as customary law (Bardhoshi, 2009), collectivization (Lelaj, 2011), urban studies (Hysa, 2011), or housing (Dalipaj, 2012).
} 
nationalism. Up to the end-1960s, the cultural revolution of national communism rested firmly on archaeology and people's culture studies to provide roots to the national-socialist state. Up to the collapse in 1989, the autarkic communism aggressively mobilized people's culture studies in the notorious campaigns against anything that was labeled either conservative manifestation or liberal attitude towards state policies. Finally, in the last two sections, we consider the engineering process of instrumental folklorism and its methodological validation in the context of the national-communist project of cultural hegemony.

\section{The folkloric glorification of one's own people's culture}

Albanian studies have been animated from the start by the pretensions to a glorious antiquity and to a millennial cultural and territorial continuity of the Albanian people (Doja, 2015). Arguably, Albanian scholars have provided abundant empirical evidence of Albanian tradition and people's culture in historical perspective, especially on material culture, social organization, or mythology and beliefs, with sometimes useful observations on social changes during socialism. Their researches are scattered in disparate publications or lost in the archives, as is the case with works on customary laws by Rrok Zojzi or on oral literature by Qemal Haxhihasani. Some works of the time have been republished in recent collections (Gjergji, 2001, 2002, 2006; Tirta, 1999, 2003, 2004, 2007; Ulqini, 2003; Shkurti, 2004; Muka, 2007; Uçi, 2007). Yet, they are often reproduced with little commentary, analysis or revision, and it is clear that they bear the mark of their time.

In Albania, as elsewhere in Eastern Europe, the field has been dominated by "national ethnography" as practiced by "native ethnographers" (Hofer, 1968), and is known as studies of traditional culture and folklore, or ethno-culture, folk culture, or better people's culture, to comply both with socialist era terminology and with word formation in English (as in "people's democracy"). The standard term in Albanian is the study of kultura popullore, ${ }^{3}$ which is often rendered in English as "studies of popular culture", taken to mean the totality of ideas, perspectives, attitudes, images and other phenomena that are deemed to be preferred within the mainstream of Albanian culture. This translation is mistaken, if not abusive, and "people-science" is undoubtedly more accurate. The concerns of the field have corresponded with folklore studies if we take folklore at its primary meaning as "knowledge of the people" or the study of "the whole of the people's traditions, customs and arts" (Eng. Folk-Lore; Germ. Volkskunde).

The institutional history of these labels is tortuous and becomes even more difficult when well-defined tracks for professional training are lacking. In Albania, as throughout Eastern Europe, the study of kultura popullore has included investigations of material culture, folk art objects, oral traditions, myths, beliefs, customs and the like. The shifting boundaries between several academic denominations, such as "folklore" focusing on oral traditions, "ethnography" dealing primarily with customs and artefacts of material culture and even "physical anthropology" dealing with racial traits, should be seen as a matter of distribution of tasks and secondary divisions within a common project of national history. ${ }^{4}$ The same applies not only to historiography dealing with ancient times, but also to archaeology dealing with remains of material culture, and to philology dealing with language relics.

Whatever the label, like native studies focused on the people's culture of other East, Central, and Southeast European countries, including Greece (Herzfeld, 1982), this kind of studies were focused on the culture to which the researcher belonged and they celebrated a national model that is supposed to be deeply rooted in the past. Such studies are conducted nationwide and the village has always been the primary location of research, despite the tremendous impact of modernization and the rural exodus that depopulated the countryside in the second half of the twentieth century. Social and economic change only made it more urgent to study the peasant milieu, now seen as the depository of a "dying" way of folk life, customs and communities. Researchers focused primarily on the urgent collection of traditions "in danger of disappearing without leaving any trace" (Zojzi, 1959, 7), something which is repeatedly recycled even in more recent collections (e.g. Gjergji, 2001, 26; Tirta, 2003). Their primary mission was to build up national culture by looking to the "folk" to document people's culture among the peasants, in the conviction that old age, cultural isolation, geographic remoteness and unsullied preindustrial

\footnotetext{
${ }^{3}$ The meaning of the term is closer to the French populaire, rather than to the English popular, which according to the Oxford English Dictionary refers to what is "liked, admired, or enjoyed by many people, held by the majority of the general public, carried on by the people as a whole, intended for or suited to the taste, understanding, or means of the general public". By contrast, according to Le Grand Robert Dictionary of French, populaire means something like "relative to the people, which belongs to and is part of the people, emanates from and is spread among the people, speaks to the people and remains within their reach, which is created and used by the people and not by the bourgeois and high class".

${ }^{4}$ In 2011, in a series of papers presented to some International Conferences and in a series of interviews and debates broadcast in some national TV channels in Albania, followed by publication in print media and reprinted in "Comment on devient anthropologue", an interlude to the Invitation to the Field (Doja, 2013b, 26-39), one of us argued that people's culture studies during state socialism were plagued by a deliberate interest in historical facts and a predominantly historicist view of one's own people's life. This does not necessarily imply that we are ignoring works dealing with the socialist present, as one of our former teaching assistants hastily believed when he reviewed some ethnographic studies on land collectivization during socialism in Albania (Lelaj, 2011). Neither it was our intention to argue against the very existence of ethnographic research in Albania; and it is certainly wrong to believe that "the debate presumed and sometimes even promoted a power relationship (sic!)" between disciplinary traditions, as some other young colleagues rather awkwardly stated, while betraying an intent of their own to prioritize one over the other (Dalipaj, 2012). Indeed, our contention, which is later developed further elsewhere (Doja, 2013a, 2015), focused form the start on the instrumental function and the politics of these studies, where we posit a perfect homology between what is intended in Albania and other East European countries as "ethnography" and "folklore", on the ground of their particular political and methodological framework in which they both functioned. What is at stake is not only their similar historicist and empiricist view of one's own people's life and culture, but also their full involvement in state ideological and institutional structures, with the duty to actively build a new field congruent with communist morality and policy.
} 
settings are deemed to reveal the nation's essential traits and the embodiment of shpirti popullor $i$ kombit, the "people's national soul", that is, the original character of people's culture and people's spirit (Volksgeist).

Actually, not only their purpose is similar to, but their methodology is based above all on folkloric data collection in the manner of German Volkskunde (Doja, 2014a), to the extent that the field of folkloric people's culture studies in Albania can be viewed as a re-working of the old German Kulturhistorische School (Doja, 2014b). They inevitably acquired both a political nationalist attitude and a methodological descriptivist and essentialist orientation. In all cases, this culturalist and historicist tradition has been institutionalized as "a deliberate, organized, conscious effort to construct a more satisfying culture" by what is known as a "revitalization movement" (Wallace, 1956, 265). In Albania, the role of these studies has been more precisely linked to Albanianism, the movement of national awakening or rebirth (Rilindja kombëtare).

Like the tradition of German Volkskunde, the history of the folkloric tradition of people's culture studies that developed in Albania (Doja, 2015) cannot be separated from the broader political and social context that generated widespread interest in the collection, description, conservation, and often exaltation of one's own nation's and people's culture, all together with the scientific ideal of a nation-state building discipline. This became part of broader native studies that native scholars, emulating German terminology, prefer referring to as Albanologie, and which are especially linked to the search for national identity in Albania. This is not, however, a specific trait of Albanian studies (Cabanes, 2004) or even Southeast European studies (Naumovic, 1998). Much the same as the German Volkskunde (Doja, 2014a), these studies have been institutionalized in Albania, as elsewhere in Central and East European countries, at a time of national movement and state building. As is generally the case with native studies, the desire to stand out from neighboring countries and the aggressive promotion of claims to civilizational superiority and antiquity were, and still are, the characterizing features of these studies. In these situations, almost naturally, a science or a group of sciences have been institutionalized in Southeast Europe, including Albania, during periods when the need was felt for a project that could specify tasks of national importance. This would confirm that there really existed a nation, and that in its pretensions to independent statehood the nation had a continuity of territorial possession and a historical legality, or at least a cultural legitimacy. The historical inaccuracy of the pretentions is not acknowledged in these projects and it is ideologically stabilized by the idea of the homogenized nation-state. As elsewhere in Southeast and Central Europe, the influence exercised by these studies and the discourse on folklorist people's culture and folk ways of life have contributed to the essentialization of the national character and have long encouraged official studies to interpret cultural difference in terms of hierarchy (Bausinger, 1993), thus providing arguments for nationalism and exclusivism.

Institutionally, Albanian studies of people's culture had a complex history under socialism, which indicates their relevance for state policy. At the beginning of the socialist period, communist leaders were initially hostile to this seemingly petitbourgeois discipline, with its curious obsession for the preindustrial peasantry who were the supposed repository of the unsullied essence of the nation. Before long, however, communist power holders concluded that such research was either harmless or useful in legitimizing their own program. Following the reorganization of the National Institute of Sciences in 1947, people's culture studies were recognized in 1955 under the auspices of the Institute of History and Linguistics. In 1960, they became a body in their own right with the establishment of the Institute of Folklore. In 1979, this institute was transformed into the Institute of People's Culture within the National Academy of Sciences that had been established in 1972. Since 2008, seeking to simulate an Institute of Cultural Anthropology, they moved out of the National Academy to be housed within a newly formed National Centre for Albanological Studies.

Within the limited changes and innovations that occurred in the socialist decades, Albanian scholars continued to deal with "the distinct cultural features of the people and their ethnic and national specificities" (Zojzi, 1959, 3), as they retrospectively extrapolated the past from the present and re-constructed backward all the historical processes of the people's cultural development. However, to put it in Kenneth Feder's terms, much of people's culture studies in Albania, together with many other thinkers, writers, scholars and charlatans, "have attempted to cast the past in an image either they or the public desire or find comforting" (Feder, 2011). Often transformed into a passion for local or national cultures, people's culture studies can exceed simple collecting, conservation and study approaches. They become a kind of cultural manipulation, FakeLore or Folklorismus, a term that could be used to refer to the voluntarist "invention of tradition" (Hobsbawm and Ranger, 1983). This attitude bears in itself important political and ideological implications for the framework of such studies, particularly likely to be entangled with nationalism and totalitarianism and which can hardly be considered to be a methodological or a disciplinary approach. Depending on countries, political regimes and ideologies, as the specific cultural practice of folklorism in the heyday of Nazi German Volkskunde showed clearly (Doja, 2014a, b), such a folklorist framework often becomes, deliberately and intentionally, the prey and fuel of political ideologies stemming from nationalistic claims or totalitarian regimes. A similar state-sponsored process, described elsewhere as instrumental "folklorism of cultural traditions" (Doja, 1998), was aimed at the indoctrination of a new mentality and the manipulation of an illusory social reality that glorified the new man and the triumph of real socialism in Albania.

In his reassessment, the first official Director of the Institute of People's Culture stated in retrospect: "The salient feature that essentially characterized the evolvement of people's culture is deeply contradictory ... The entire history of people's culture studies is a contradictory process ... This contradictory character affected the assessment of people's culture, both the national folkloric-ethnographic manifestations and the sciences dedicated to study them ..." (Uçi, 1997, 173). Actually, changes in state policy towards foreign political and ideological allies were followed by oddly ambivalent attitudes towards people's culture studies, reflecting various periods of Yugoslav, Soviet or Chinese influences that can be clearly distinguished in the history of their development. Every time the communist regime considered nationalism as a useful ideological 
instrument, the folklore of the past was vividly supported. When nationalism was considered a revisionist ideology, especially in the periods under the influence of utopian ideas of the internationalism of socialist life, people's culture was downgraded as a "primitive anachronism" (vjetërsi anakronike). In retrospect, the half a century of communist dictatorship in Albania, like the other communist revolutions in Eastern Europe (Osiatynski, 1991; Chirot, 1991), marked the gradual shift of people's culture studies from a supercilious internationalism to a national socialism followed by an autarkic communism, which could somewhat explain the "missed transition" (Abazi, 2010, 2011) in the current crisis of post-communist studies.

\section{Sovietization and de-Sovietization}

In the immediate postwar years, throughout Eastern Europe, the euphoria of a partisan culture following the victorious imposition of communism introduced a series of new challenges, including reconstruction, decolonization, and the "friendship of the peoples", all of which testing interwar definitions of nationalism and internationalism. In this context, a policy of supporting people's culture in Albania turned to be inconsistent with the conception of nationalist forces relegated to collaborationists of fascism and with the kind of internationalism promoted at this time in the Soviet Union and in Yugoslavia, with which Albania was especially allied. The communist regime of Enver Hoxha displayed a watchful internationalism, considering cultural heritage as a manifestation of nationalism, even though this attitude must have been accompanied by giving up any claim to Kosovo that was returned to Yugoslavia after the War.

At this time, Albanian cultural production was bound to follow the method of socialist realism, officially established at the Third Conference of the League of Writers and Artists in October 1949. In this context, the meaning of people's culture also started to be dismantled and in its place another code of meaning was created and put to work, subject to the new cultural pragmatics of real socialism. This process induced a type of discourses, activities and knowledge productions on people's culture, which increasingly turned into a new way of thinking and a new array of devices to explain and interpret the whole cultural system and social life. The appearance and the mechanism of a different cultural semiotics, based on a new cultural code paralleling the pragmatics of Albanian language and literature (Vehbiu, 2009; Yzeiri, 2013), served to signify the new framework of notions and concepts of the communist era.

In the 1950s, after the break with Yugoslavia in 1948, Albania was more strongly affected by Soviet infiltration. The Party leadership and the totalitarian state simulated Soviet experience and applied dogmatically the Stalinist characteristics of Soviet development. In this context, the folkloric (Volkskunde) tradition of people's culture studies had another tradition, seemingly quite different, grafted on to it. Under the label of etnografi, like Ethnographie in East Germany (Doja, 2014a), people's culture studies in Albania emulated the methodology and terminology of Soviet etnografiya and ethnos theory. As in other East European countries (Valtchinova, 2004; Hann et al., 2005), they followed the logic of the latter's development and separation from folkloristika, which is examined in more detail elsewhere (Doja, 2015). In brief, such studies tended to privilege and celebrate the material framework of people's life, which corresponded to the axiom of the determinant character of the material world and labor value in Marxist social theory.

The material culture of traditional rituals and customs was separated from inward culture (kultura shpirtërore), which was in turn separated from the study of verbal and musical arts, as distinct sub-fields of people's culture studies. The category of "people" in people's culture (kultura popullore) slipped easily from connotations of traditional and archaic into the political equation of people with nation (kultura popullore-kombëtare). Culture was conceived as a core characteristic of a deliberately ethnicized concept of folk (etnokultura), paralleling the concept of "ethnos" in Soviet etnografiya (Bromley and Kozlov, 1989). These conceptualizations were increasingly associated with an additional socio-class understanding of the "people" in contemporary socialist society. This process led to a specific concept of a common people's culture that ought to be shared by the "people" as a working class. This radical conceptualization actually paralleled the elaboration of the concept of "people" (Volk) in East German Volkskunde where a specific and exclusive socio-class category of "demos" was distinguished from the more general ethno-cultural category of "ethnos" of the Soviet etnografiya (Noack and Krause, 2005, 42).

Surely, as shown elsewhere in more detail, a homology between German Volkskunde and Soviet etnografiya can be posited on the ground of their particular political and geopolitical frameworks (Doja, 2014a). However, the recognition and accentuation of people's culture as the socialist culture of "working people" (populli punonjës), namely the oppressed people, who according to Marxist ideology are uncompromisingly opposed to exploitative classes, was an important consequence of Leninist theory of two exclusively differentiated national cultures in class societies. In its dogmatic interpretation in Albania, class struggle was a positive factor, which also meant that the disruption of the unity and homogeneity of people's culture at the national level was recommended for the people and for the nation. Insofar as the people and the nation were thought to be only the previously exploited and oppressed, everything else was excluded from people's culture, especially whatever could show or include the cultural forms and practices of any other societal group. Culture was still divided into material versus inward, but emphasis was placed on the degree to which culture was appropriated by the individual as a member of the working people.

From the start the Party Way journal proceeded with direct and concrete instructions to implement the class struggle of the working people, by targeting especially the political education of the youth (Rruga e Partisë, 1955/11, 36-47). Hoxha constantly urged party workers to flesh out the class struggle project of the working people with the ongoing struggle against the "old vestiges" (mbeturina të vjetra) of the past and against any element that displayed signs of the alien ideology of bourgeois morality, which meant the "old-fashioned people" (njerëz të vjetër) who are the enemy of the people and socialism, above all the religious, the intellectual, the former landowner, and their family circles (Rruga e Partisë, 1955/11, 43). On behalf 
of this principle, some of the brutal campaigns were launched to disintegrate and destroy the so-called reactionary and alien cultural influence of the Catholic Church and Highlander chiefs in the North, the so-called old and alien culture of former landowners in some of the predominantly Muslim areas like Delvina in the South, and the so-called bourgeois and alien culture of Western-educated intellectuals and professionals in both Muslim and Christian circles, North and South alike, simply because they were judged to be irreconcilable with communist morality and with socialist culture.

During this period, the task of people's culture studies was to investigate the material and inward culture of Albanian people, as in East Germany and other East and Southeast European countries (Hann et al., 2005; Mihailescu et al., 2008; Boskovic and Hann, 2013), from a broader perspective of studying socialist transformations and new ways of life in contemporary socialist society leading to a socialist nation-state. Definitely, they were urged to apply the Stalinist concept of building a new people's culture to be "national in form and socialist in content" (Zojzi, 1959, 9).

For a long time Stalin's notorious formulation of culture in socialism was repeated as an absolute truth, even though this was in itself nonsense because the plurinational composition of the Soviet Union was not applicable to a small and ethnically homogenous country like Albania. As a result, people's culture studies in Albania isolated themselves from the experience of other academic traditions. In their rush to adopt Soviet descriptivist models, they even disregarded the national character of one's own culture. In particular, the so-called houses of culture, with the creation of amateur ensembles of folk dance and music, were turned into centers for the kind of folklorism of people's culture that undermined important cultural features, by using and misusing folklore for the instrumental political purposes of the days.

The pivotal tense moments of the Soviet Twentieth Party Congress and the crash of the Hungarian uprising in 1956 showed that the de-Stalinization process in the Soviet bloc ironically helped to create many new Stalinist characteristics (Jones, 2006). From the onset, after breaking with the Soviet Union at the beginning of 1960s, the de-Sovietization period in Albania became associated with the cultural realm (Mehilli, 2011), which could tolerate no peaceful coexistence. Even though Khrushchev's revisionism increasingly served as the implied target for Hoxha's criticism, the real victim was the general population within Albania (Blumi, 1999). However, Tirana Party Conference in 1956 showed that the rhetoric of conflict was not targeted against disgruntled former landowners, hostile highlander chiefs, and the meager Western-educated professional circle of the interwar period. Rather, Hoxha and his main men launched a wide-ranging witch-hunt to crush the new overwhelmingly Soviet-trained professional class that permeated Albanian state. The primary task was to redefine a new culture despite the enormous human capital invested into indoctrinating a generation to associate Soviet Socialism as a cultural model for Albanian society.

In this context, people's culture scholars in Albania found themselves in a paradoxical situation. On the one hand, they still relied on Soviet experience and methodology and they defended the old principles of Soviet etnografiya, all together with the Stalinist dogmas of the people's culture "national in form and socialist in content". At the same time, they condemned any achievement and innovation in their constant claims at contributing to the ideological campaign of a total war against Soviet revisionism. This situation, as a matter of fact, created an even greater isolation from any other academic tradition, which reinforced a more dogmatic attitude towards the Soviet experience itself.

Not surprisingly, at this time the so-called etnografi studies were even "understood to have been born with people's culture and traditions ... to protect the people during difficult historical periods" (Hysa, 2013, 137). Obviously, in this understanding, they could be more easily instrumentalized towards cultural regimentation and systematic distortion of history, which enforced isolationist ideology and ethnocentric attitudes. They nevertheless posed a serious obstacle to the creation of a desired socialist culture. It was not clear whether the force of tradition could be resisted along with the other so-called foreign reactionary and nihilistic influences that threatened the establishment of socialism or they must be fully taken at a new task in securing the revolutionary transformations into socialist society against any influences from the so-called alien and exploitative manifestations of learned culture (Zojzi, 1959). In the next years, following internal purges and public displays of redefined ideological orthodoxy, people's culture studies were mobilized in remarkable ways. They were used to support the masses in mounting another brutal campaign that culminated with the Cultural Revolution in the 1960s.

\section{Further revolutionization and mass studies}

In the 1960s, after breaking with the Soviet Union and allying itself with China, an Albanian variant of the Chinese Cultural Revolution took place to mobilize people's culture knowledge as a way to service the evolving ideological claims of the communist regime. The new policy, first enunciated by Enver Hoxha in his Report to the Fifth Party Congress in November 1966 (further referred to as: Selected Works, IV.114-208), instated a series of major campaigns of Stalinist purges that came to be known for their "further revolutionization" (revolucionarizimi mëtejshëm) of the whole socialist ways of life in Albania. ${ }^{5}$ In a notorious speech of February 1967, Hoxha called for an intensified cultural struggle against religious beliefs and the complete destruction of organized religion (Selected Works, IV.209-251), assigning to the youth movement the antireligious mission of "creating the first atheist nation-state in the world", which was finally sanctioned by the new Constitution in 1976 . Another speech of June 1967 inaugurated a movement for the emancipation of women aimed at the family revolutionization and liberation from the remnants of the conservative and patriarchal mentality of bourgeois ideology (Selected Works,

\footnotetext{
5 Earlier editions of Hoxha's Selected Speeches were typically titled “On further revolutionizing our Party and the life of our country as a whole", Speeches 1967-1973. (In future referred to as: Speeches).
} 
IV.261-284). Party workers, communist intellectuals and faithful scholars have continuously tried to rationalize the policy, ${ }^{6}$ or exhort the youth. ${ }^{7}$ The obvious effort was to root out some of the old prevailing customs and traditions, paralleling Mao's slogan that sums up the excesses of Cultural Revolution, “smash the four olds" (破四旧), which in 1966 exhorted the youth to destroy anything regarded as "old”, loosely defined old ideas, customs, culture, and habits.

More than anything else the "further revolutionization" campaigns firmly mobilized people's culture studies in the struggle against "backward customs" (zakone prapanike) that were deemed to be related to either religious beliefs or customary behaviors. Hoxha tactfully pointed to some "troubles" with the Party in the North and with people's culture scholars explicitly. He recommended the full assessment of Gjeçov's work on customary law to "help scholars to make a good diagnosis of the existing state of social relations in the North, in order to see their radical transformation, their evolution, and to strengthen our ideological, organizational and propaganda work" (Selected Works, IV.272). This research recommendation turned to be important not only for the North, but also for Central and South Albania where due to a more advanced development there was not a concentrated expression of custom. "These parts of our country, Hoxha warned, were not free from some unwritten laws which are nothing else but the customs we are talking about, which were governing and directing the life of the people, families, kinship groups, etc., in a barbarous way in these parts of the country as well" (Speeches, I.143). He urged unequivocally that from people's culture and folklore "we should preserve what is good, what is of the people, what expresses the pure sentiment of the people and we should discard that part, in form or in substance, into which has penetrated the ideology and inspiration of the ruling classes, of the lumpen petty bourgeoisie" (Speeches, I.290-291).

In this process, not only creative writing stopped to be viewed as a personal product of talent (Yzeiri, 2013), but also people's culture came increasingly to be regarded as the superstructural product of the inspiration of the communist era. In a way, after they took power, the communists acted as new apostles to provide a revised collective memory, with which they started to build a new culture. To this aim the communists used another code of their own, based on a kind of descriptive discourse on our people building our culture, which became prescriptive and exclusive. Not coincidentally, party ideologues contributing to the Party Way journal already stressed that people's culture understood as artistic activities and groups of folk songs and dances was a very narrow concept of people's culture. Intended as a much broader concept, people's culture ought to "include all areas of people's material and inward activity, relating to politics, ideology, morality, lifestyle, ethics, and above all to work and production” (Rruga e Partisë, 1967/3, 33).

In February 1969, the Party Central Committee's Institute of Marxist-Leninist Studies organized an influential conference on "some issues of social studies". In her keynote report, Hoxha's wife and Director of the Institute claimed unambiguously from the start that social sciences are extremely important for the communist education of mass workers. She called for an explicit instrumentalization of social studies, urging practitioners to show their positive effects on the propaganda and education strategy at the party service. Among other things, she stressed the necessity to reassess "the data on people's customs and lifeways collected by foreign travelers a century ago in different areas, and after submitting them to a Marxist-Leninist prism, we can use them for comparisons with today's transformations in our country" (Rruga e Partisë, 1969/3, 62).

In his address to the conference, the Director of the Institute of History and Linguistics (where people's culture studies were based at that time) assigned more explicitly this urgent task to people's culture scholars. He urged that customary vestiges, in any various forms together with any other backward customs, futile beliefs or religious prejudices must be seriously investigated in every area, in every village and in every individual to disclose their supposed deep roots. People's culture scholars should better reassess the ways in which these vestiges may persist in people's life and may hold back the development of socioeconomic, cultural and ideological revolution both in the North and in the South. Such a research is clearly linked to the ideological struggle for the triumph of new principles, aimed at strengthening party propaganda by highlighting the real facts of socialist transformations in the whole Albanian areas throughout, North and South alike (Kostallari, 1969, 120). In practical terms, data from the systematic investigation of old traditions and backward customs were "used by party committees and organizations to improve the value and impact of ideological and organizational work of the party". Simply, "they provided a more solid basis to improve analyses and syntheses in the ideological party work with the people" and "they definitely helped party workers to better know the people and more easily convey the party line to them" (Kostallari, 1969,128). In this way, custom and tradition are not merely an object of study; they rather become a means to the ends of communist policy.

In this context, if the people was the subject producer of culture, the research process also required an activation of the socalled "mass studies" (studime nga masat) under the leadership of local party committees and state bodies. In the first place, "this task must be taken as a continuous collective action of teachers, agronomists, veterinarians, physicians, midwives and even villagers, farmers and stockbreeders in every district and every locality" (Kostallari, 1969, 129). Remarkably, the handful research staff in Albania at this time relied on a considerable number of local assistants who provided almost exclusively the institutional archives with data from the field. Under the leadership of party workers and officials, they came predominantly from the mass of workers who were set to the task of carrying out social investigations. As Hoxha himself have clearly indicated, all must be involved in the so-called social studies: this "complicated job calls for convincing propaganda, a thoroughly scientific propaganda" (Speeches, II.224). In this way, a close relationship was established among the party apparatus, the research apparatus and the state apparatus, including the notorious Security services (Sigurimi) in charge of

\footnotetext{
6 Rruga e Partisë 1960/10:50-58, 1961/7:57-70, 1967/3:18-25, 1967/5:45-57, 1978/5:70-80, 1984/4:26-35, 1986/3:61-73.

7 Rruga e Partisë 1955/11:36-47, 1961/11:26-32, 1965/5:12-25, 1967/6:38-51, 1972/11:45-52, 1978/5:48-58.
} 
keeping the party constantly informed (Nikolla, 2011, 106-107). The Director in charge of Marxist-Leninist methodology urged for the downright completion of data collection and fact-finding with "the key reports and any records found in the files of the party apparatus, the state apparatus and the mass organizations" (Rruga e Partisë, 1969/3, 61).

In his speech, the Director in charge of people's culture studies declared forcefully that more than anything else customary laws were a synonym of "ideological illness and cultural backwardness coming from the past, from which society could only recover with the strength of Marxist-Leninist ideology" (Kostallari, 1969, 131). Similarly, another speech to the same conference by soon-to-be the most influential Director of the Institute of People's Culture Studies provided full Marxist-Leninist theoretical and methodological rationalizations to lead the emancipation of women and the transformation of family relations (Uçi, 1969). In the aftermath, people's culture studies were directed to systematically assist in bringing MarxistLeninist ideology into practice by instrumentally engineering, rather than analytically studying, the folklorism of people's culture.

By the late 1960s, the intensification of class struggle against reactionary and antiquated customs, religious prejudices and old ways of living granted new tasks to Albanian people's culture studies. In a review article, two leading people's culture scholars "urged to discover the historical roots and fight the reactionary philosophical foundations of corrupt customs that were holding back the development of society". There is no doubt that they and their colleagues "consciously focused their efforts on replacing them with new customs", thus "directly contributing to the solution of the major duties set forth by the Party toward the further development and intensification of the ideological and cultural revolution in the country" (Dojaka and Gjergji, $1969[1972,12])^{8}$

In this way, people's culture studies could reflect only one reality, "the objective process of development of society towards communism", because dialectical-materialist generalizations could be only made by indicating the right way to revolutionary practice. This was the only way for them, the Director in charge of Marxist-Leninist methodology claimed, to provide a profound scientific analysis that uncovers the contradictions and their causal origins, explains tendencies of development along the struggle of the new against the old, and shows the measures that should be taken to eradicate the old and open the way to socialist innovation (Rruga e Partisë, 1969/3, 63). In other words, some cultural cleansing was needed to build a new people's culture.

\section{Building a new people's culture}

Precisely at a time when the "Chinese" period in Albania was going to its end, the Albanian variant of cultural and ideological revolution reached its political high-water mark. In the 1970s, a new phase of "permanent revolution" ultimately launched even a more severe class struggle against religious beliefs and backward customs. A large part of this struggle was taken by condemnations of attitudes towards people's culture, which came under disciplining in the course of the new ongoing doctrine, according to which the "people" ought to belong to a unique and irreplaceable nation-state that built the real socialism. In his address to the Party Plenum in June 1973, aimed to intensify the ideological struggle against the influx of "alien and conservative manifestations" and against the so-called "liberal attitudes" taken toward them (Selected Works, IV.812-849), Hoxha went on to charge on the misrepresentations of archaism and folklorism. He denounced the "openly scornful stand towards folklore and its great artistic and social values", which was deemed to be the cause and to serve as an argument to justify "departures from the sound national background" in professional art and literature (Selected Works, IV.825). In short, the principle of class struggle aimed at the identification of both "liberal" and "conservative" aspects of people's culture. A new substance of cultural and educational activities, new ways and means of realization of the new culture were encouraged to penetrate more in people's ways of life, both in family and individual lives, both in Northern and in Southern areas (Rruga e Partisë, 1968/7, 19-25). In this way, further elaboration and transformation of people's culture was subjected to the principle that people's life is overall a socialist culture and that every aspect of social life should be used toward people's cultural, ideological and political education (Rruga e Partisë, 1973/4, 7).

The socialist revolutionization experiment is best mirrored in the painstaking concept of building and refashioning what had often been referred to as a revolutionary communist New Man, paralleling the formation of Soviet Man (Heller, 1988), and imagined to be a prototype of the new "people" and an alternative to both Western decadent and Eastern revisionist subjectivity. The new man arose as a moral model, very soon turned into an instrument of war and persecution against all those regarded as "old" and not complying with the norms of communist morality advocated as "new" (Nikolla, 2011). The revolutionary communist education of the working people was for Hoxha a process of the "active, merciless and principled class struggle against all the stains and influences of alien ideologies, whether feudal, patriarchal, bourgeois, petty-bourgeois, or revisionist" (Speeches, II.90). This destructive vision of communist morality transformed the new people's culture into a direct ideological claim and war instrument to "smash the reactionary influences of the foreign bourgeois-revisionist culture and the conservative, clerical and patriarchal elements of the old petty-bourgeois culture" (Rruga e Partisë, 1972/8, 37-39). The further development and improvement of mass cultural work was closely linked to the elaboration of a broader concept of people's culture, enlarged to all the many aspects of social activity and the whole range of socialist ways of life (Rruga e

\footnotetext{
${ }^{8}$ Oddly enough, the same statement is reproduced almost verbatim in recent collection (Gjergji, 2001, 15), while nearly identical statements continue to be reproduced in other compilations (Tirta, 2003).
} 
Partisë, 1978/3, 58). In this context, the demarcations between material and inward culture, or ceremonial and artistic performance, and other dichotomous forms that emerged within the reformed conceptualizations of people's culture, further obscured the structural and functional bases of cultural practices.

A programmatic paper presented to the National Conference of Ethnographic Studies in 1976, which can be considered to have laid down the main principles of the transformation of the Institute of Folklore, and perhaps facilitated the appointment of the first official director to the reformed Institute of People's Culture in 1979, was especially intended to record the effects of time and the changes occurring in social conditions and ways of life under socialism (Uçi, 1976). ${ }^{9}$ As he stated, "a typical and very interesting renovation of folklore" was the modification of its functions, assumed to be "a critical appropriation of people's cultural heritage motivated by socialist ideology". Although the people did not entirely lose their inward life, the religious, magical or ceremonial functions of people's culture were assumed to have "atrophied", but "increasingly activated in the people's inward life with artistic-aesthetic functions" (Uçi, 1976, 79-80).

Eventually, an additional dimension was gained for the concept of nation's and people's culture. It was increasingly associated with socialist culture and the socialist ways of life, and therefore revaluated as a national pride and patriotism for the state socialism. In his address to the National Conference of Ethnographic Studies in 1976, the President of the National Academy of Sciences described how people's culture studies had to balance both nationalist and communist ideologies. To this aim, researchers had to "engage in the major processes of revolutionary cultural transformations" and "contribute to the socialist emancipation of Albanian society" by "capturing those essential aspects (of class struggle) that assign the place and role of people's culture in the creation of the new socialist culture" (Buda, 1977, 33-34). In other words, researchers should not merely collect traditions of people's culture. They must both study and transform the collection of survivals of old ways in order to construct the full hegemony of a new morality.

The application of this ideological program was multi-faceted. In order to unearth patterns of human creativity in rural life, these studies emerged out of the application of individual specializations of high culture to a detailed knowledge of people's culture. Although the importance of material culture was emphasized, people's culture was primarily defined in terms of orally transmitted memories and traditions, which excluded other forms directly shaped by the higher literate character of learned culture. Definitely, people's culture studies were interested in folk art and crafts, festivals and holidays, folk song and dance, as these were assumed to reveal the distinctiveness of the villagers, their creative skills, their aesthetic sense, and other values that learned culture had allegedly ignored or separated from the culture of working people.

Simply put, a new position was tried for the culture of rural society in the spectrum of cultural values. The performance of folklorized activities by the rural people was proclaimed to be an assertion of "their new personality as members of the socialist community, promoting the new aesthetic ideals and the new worldview and psychology, and embodying the transformations in the ways of life and the new higher artistic preferences" (Uçi, 1976, 87-88). The people of rural society were by now supposed to have been "enlightened" and to have long abandoned their archaic way of life. After "the communist principles were their guides", they ought to be deeply conscious of the ongoing and overall transformation of the socialist society. Even the further revolutionization and mass production of culture was taken over by workers and peasants who were claimed to become both object and subject, both consumers and producers of socialist culture (Rruga e Partisë, 1972/8, 36-45).

After the Party and Hoxha himself basically monopolized the formulation of ideology and methodology, social research became fully dominated by indoctrinated propaganda. In this context, folk costumes, songs and dances were promoted and folklore cultivated in Albania not simply to give people a sense of their creative and authentic past, to only construct a highly specific cultural identity and hand it down to later generations. Likewise, Albanian studies were not intended to provide accurate knowledge about people's culture, language and history. Above all they serviced the ideological purposes of the construction of real socialism and supported the shifting state policies of the communist regime.

In the aftermath of the 7th Party Congress in November 1976, when Hoxha regime instated a tough period of total isolation in Albania (Selected Works, V.1-137), efforts within people's culture studies shifted to foster a sense of ethnic compactness, authenticity and superiority against the identity of neighboring Slavic and Greek cultures in a way that at the same time allowed them to argue that Slavic and Greek neighbors were exercising hostile influences from which our peasants and workers could be inwardly corrupted. People's culture was praised for its integrative function to maintain and transmit local and national traditions (Uçi, 1984), while the higher arts of learned culture were considered dangerous because they could build bridges of communication with the alien culture of other peoples.

In this context, the Albanian variant of the permanent cultural and ideological revolution promoted a nearly hysterical struggle both in defense of the national character of the socialist people's culture and against the enactment of tradition as an integral part of village life, thus isolating it even further from other cultures. Clearly, the reformation campaign of people's culture studies was used to pave the way for arbitrary intervention and bureaucratic administration in order to maintain people's life and people's culture under tight party control in the years to come.

\footnotetext{
${ }^{9}$ To his merit and to the best of our knowledge, Alfred Uçi is the first and by now almost the only scholar of the old generation to assess critically and reflexively the evolution of the discipline during socialist period in Albania (Uçi, 1997), even though he skillfully slipped away from fully acknowledging his own responsibility for many of the developments that are the target of criticism.
} 


\section{Engineering folklorism}

During socialism in Albania, the Illyrian obsessions of native archaeology, the obsession of native Albanian studies as a whole with the problem of ethnogenesis, and the obsession of people's culture studies with the problem of authenticity, were brought together with the obsession of socialist studies to provide evidence and legitimate the so-called authentic way of building socialism and communism. This lead people's culture studies to adopt a practical thinking borrowed from the ideological dogmatism of empiricist materialism (Abazi, 2010, 2011), which encouraged descriptivism and folklorism.

The establishment of a totalitarian regime, the forced collectivization of village economy, the impoverishment of rural peasants, the bureaucratization of social life, the repressive measures against anything that could not correspond to party ideology, the further revolutionization that escalated the so-called permanent cultural and ideological revolution, all resulted in narrowing the scope of people's culture in social life, levelling out the diversity of living conditions and the content of human existence. Albanian farmers, for instance, had been dispossessed and were either "proletarianized" by their entry into agricultural cooperatives, or "urbanized" by their migration into the newly mushroomed socialist cities, or "systematized" by other means of centralized measures. Nevertheless, the image of a thriving virgin and socialist people's culture, rooted in a pre-socialist and non-capitalist tradition, was propagated by the state ideology and cultivated and administered by the practitioners of people's culture studies.

It seems that the notorious disinterest of these scholars in theory must have influenced their conduct in the field, leading them to reconstruct data about archaic forms and ways of life wherever such data were lacking. Many of these scholars had adopted a very unethical behavior, adjusting their purported findings to the official dogma of communist ideology and propaganda. Much of people's culture studies were for a long time in charge of the state of today affairs (çështje të ditës) and the so-called socialist changes in ways of life. In this task, many scholars often indulged in ethnographically validating the dispossession and proletarianization of Albanian farmers, their urbanization and systematization. Among other things, scholarly narratives on customary laws and other traditions of people's culture were manipulated to justify the formulation of state policies and the adoption of certain political solutions leading in many cases to cultural, social, and economic disasters. Yet, with the generalized isolationist and autarkic paranoia in many realms of social life, many ethnographic accounts and other studious rationalizations justified the disastrous collectivization of land and livestock (Haxhiu, 1963; Gjergji, 1963, 1965, 1968, 1973; Shkurti, 1976; Qarri, 1976; Luari, 1977). Obviously, these were presented in light of socialist economic developments and the so-called great transformations from traditions to modernizations in the people's ways of life, including the necessary leveling out of differences between urban and rural areas, between highland and lowland areas, between northern and southern areas (Gjergji, 1963, 1965, 1968, 1973, 1979, 1981, 1983, 1984, 1985, 1986, 1987; Tirta, 1982, 1985, 1986, 1987). Their main rationale was to be in accordance with the principles of a socialist society and the requirement of party leadership.

People's culture scholars made every effort to reconfigure customary practices that were ideologically at odds with socialism, while official impressions of Albanian culture were heavily mediated by the domesticated paraphernalia and often romanticized depictions of village life that were safely housed in the national museums and propagated in official publications and cultural activism. Folklore festivals, more than anything else, were straightforward celebrations of the socialist ways of life and the national pride of real socialism. They promoted the production and performance of theatrical cultural practices, which were to be applied throughout the nation to the detriment of local variation. Even when regional differences were showcased in the annual National Folklore Festival, arts and customs were wholesomely detached from any supposed "backward" practices. So, the traditional lover in old urban settings, deemed to be influenced from backward Ottoman or Oriental culture, was substituted with the new man and working youth in national factories or cooperatives where true socialist love could only be born. In this way, folk songs, dance and costume were separated from the people's rituals and festivals in order to service the new party rituals. They were activated in party celebrations, in historical anniversaries, during visits of the party leaders, in meetings with podiums and presidiums.

The increase of theatrical cultural practices and higher artistic simulations brought to the fore the problem of people's culture change. It had to be articulated with the so-called socialist cultural revolution (Xholi, 1977; Uçi, 1976), in what came to be known as the new folklore movement (Uçi, 1980). The new folklore movement was propagated as a sign of "accelerated revolutionizing progress", as the "people's break from the backward past and the primitive ways of living and thinking", as a step that "connected and included the people to the mainstream of contemporary progress and civilization" (Uçi, 1976). To justify the policy of continuity in folkloric tradition, socialist culture was thought as an inherited essential part of people's life and activities, which ought to explain why "men and women joined their strong, resonant voices together to develop a vibrant people's art" in accordance with party ideology and socialist achievements.

In this process, practitioners of people's culture studies were brought to task to provide pseudo-scientific rationalizations of this vision (Sako, 1975; Uçi, 1981; Xhagolli, 1988). To match Party directives, they outlined the criteria for organizing folklore festivals and reproducing traditional costumes (Zojzi, 1975; Dojaka, 1975; Gjergji, 1975, 1977), they supervised the innovative trends in folk dance and music (Bogdani, 1977; Kruta, 1977), they evaluated the social and cultural status of performers and actors (Shituni, 1988), and they produced descriptions of these performances that were all aimed to track the so-called expansion of new folklore (Panajoti and Kruta, 1986; Shituni, 1989; Uçi, 1989).

In many ways, people's culture was instrumentally manipulated to be tightly bound to the rampant cult of Enver Hoxha. The National Folklore Festival was held at the birthplace and on the birthday anniversaries of Enver Hoxha, hailed as the people's supreme leader. Together with the Party, he became the central figure of the so-called new folklore as a whole. 
Practitioners of folklore studies unabatedly tried to substantiate the claim (Fico, 1979). They also produced a series of data collections from the National Folklore Festivals, which focused explicitly on Enver Hoxha and the ruling Party (Xhagolli, 1983; Shituni et al., 1986). The activism of people's culture took the dimensions of a collective hysteria especially at his death. A twovolume set of folkloric texts was immediately compiled and published in the prestigious Albanian culture heritage series of the National Academy of Sciences (Uçi et al., 1985), followed by another volume of folkloric songs with musical partitions (Kruta et al., 1986). In this way, people's life was deemed to be totally transformed into an altered conscience, instrumentalized by party ideology, to legitimate the communist regime by singing hymns to Party leaders.

The absolute priority given to the principle of class analysis made it possible for the so-called new folklore or folklore of the working class to be artificially promoted as an integral part of both people's culture and higher artistic culture, which ought to represent the ideals, the principles and the models of the higher arts of socialist realism (Uçi, 1982). In this way, as showed in more detail elsewhere (Doja, 1998), people's culture studies were in charge of validating the officially enforced pseudo-values, ideals and worldviews that were artificially fabricated under the pressure of party ideology, but supposed to represent the positive changes in people's lifestyles, all together with the social, economic and political changes, and the achievements of the so-called cultural and ideological development of permanent revolution in Albania.

\section{The national-communist project of cultural hegemony}

The authoritarian ideology in service of the political class in power seems to hide behind the discourse on the so-called authenticity and new folklore movement that flourished in the official people's culture studies during socialism in Albania. The reference to traditional values, often ignored or deliberately misrepresented and manipulated by those in positions of authority, was most frequently the opportunity of an absolute exercise of power. What passed for local authenticity was generally reduced to a show of national costume, displays of certain external folkloric traits, the maintenance of dance troupes or the organization of folklore festivals intended to celebrate the rule of politicians in power and their deeds. In a more concrete way, these attitudes indicated elite distrust, and even their contempt, for all forms of cultural creativity produced at the level of basic social units, which escaped their direct control.

The instrumental folklorism was usually guided by the intentions and goals of Party elites. Their policies were mainly based either on ideological and political premises or on sheer hegemonic or economic interests, and often on a combination of all of them. As a result, people's culture studies seemed to thrive in those years in Albania. They were upgraded, respected, and deemed important for the nation-state, like Volkskunde was in Nazi Germany (Roth, 1998). New research positions were created, the institute and the archives of people's culture were reorganized, ethnographic museums and folklore festivals were established, permanent exhibitions were travelling around the world, vast research projects were funded, and numerous studies were published which reached larger than ever audiences. As an immediate result, people's culture studies were distorted as to reduce "people" to a working class and they were urged to exclusively study these people's culture in their contemporary socialist society. Not surprisingly, they have largely, and at times almost completely, surrendered their academic ethos and integrity, their theories and methodology, their institutions and most of their representatives to the propagandistic machine of authoritarian policies of a totalitarian state.

Like in other former communist-ruled countries, the manipulation of the past and the present was the responsibility of politicians and official writers, historians, philosophers, economists, and social and cultural scientists (Tarifa, 1996), including archaeologists, philologists and the practitioners of the prevailing people's culture studies, especially in their fixation on a peasant and working people's culture. Generally, in whatever field none of them remained unaware of the connection their work had with the political interests of the communist regime. However, like their fellows in other former socialist countries (Shanks and Tilley, 1992), many may now wish to deny it and maintain ideas of academic neutrality or blame their own setbacks on the ideological influence of the Albanian dictatorship and censorship (e.g. Tirta, 2003, 87; Xhagolli, 1997). They may even tell their students and younger colleagues, who often accept naively or by a sort of blunt corporatism, that the style of their descriptive works on material culture was just empirical, technical, or simply scientific, at least based on fieldwork data. This may allow them, to their own satisfaction, claim having resisted the formal political and ideological discourse or the theoretical analyses drawn from historical materialism.

Surely, it is unrealistic to think that simply one cannot or should not allow oneself to be part of the political landscape. It is also inappropriate to tell what social scientists should or should not do. The problem is more serious. Quite often Albanian scholars have been seeking the support of politics and state administration to secure a comfortable academic position. Not only was this the case for scholars holding high-ranking academic offices and affiliated with the communist party, namely almost all directors of research institutes at any time during the communist regime (a situation that continues to be so), but also for well-respected scholars, in high esteem for their German education and seemingly not involved in politics, such as, Aleks Buda or Eqrem Çabej.

The nation-state model and teleological view of Albanian official historiography, obsessed as it were both with Illyrian heritage and with socialist transformations, developed in communist Albania after 1945 thanks to Genosse Aleks, the venerable President of the National Academy of Sciences "and his Party" (Schmitt, 2005). Likewise, the dead-end in the official development of historical philology and Albanian studies as a whole, stuck as they are in the nineteenth century, owes much to another emblematic figure. Although Eqrem Çabej had been actively promoted by Monarchic Albanian, Fascist Italian and Nazi German regimes alike, and even offered a ministerial position in the government of German-occupied Albania (Martucci and Genesin, 2012), he was able to become the unchallenged paradigmatic scholar during the communist era, in spite of the 
communist regime reputedly so much intransigent towards Western-educated intellectuals of old and occupying regimes. That being the case, it is not surprising why he chose to undermine the modern interest in theoretical linguistics of his colleagues. As a result, theoretical insights such as contrastive analysis and communicative intellection worked out by Selman Riza or Osman Myderrizi "have remained sideways" within Albanian studies. ${ }^{10}$ By contrast, Çabej moved backward to the descriptivist and historicist regularities of diachronic sound changes (Lautgesetze) advocated by the old German school of Junggrammatikers. The historicism of this methodological choice reduced the object of linguistic investigation to the descriptivist empiricism of surface phenomena, such as the essentialist description of the historical change of Albanian language, but also proved to be essential to compromise Albanian studies as a whole, in order to comply with party ideology that aimed at the essentialization of Albanian ethnogenesis.

Some scholars might have made even successful personal contributions toward the professional destruction or physical elimination of their colleagues, by denouncing them, by recommending that they lose their jobs, and so forth, as it has been the case in almost any other aspect of public life during the purges of further revolutionizing campaigns in Albania. Actually, quite a number of decent scholars suffered serious setbacks in their careers due to denunciation to the political police (Sigurimi) or because of political pressures from the Party (for example, Osman Myderrizi in the field of Oriental studies or Qemal Haxhihasani in the field of oral epic poetry). Many of their research results were internally censored before being academically accepted, let alone published, if publication was granted at all.

Clearly, the dominant development of people's culture studies in Albania, like the Albanian studies as a whole, was the ideological distortion at the service of the communist regime. They were characterized by a political situation in which both the scholars and their research subjects defined, articulated, constrained and shared with each other the same existential condition (Lelaj, 2011, 220-221). The finality of their interaction, whether intentional or not, was to create a continuous basis of legitimation to building state socialism and strengthening dictatorial regime in Albania. Surely, propaganda in some academic works was merely fulfillment of a rhetorical minimum obligation. Yet, some of it came out of intention and conviction, and some was opportunistic flirtation with what seemed to be the fashion of the day. Many scholars were not as much concerned with the reception of their work in academic circles or in the larger public as they were concerned about the opinion and the support of certain party leaders. Most of the leading academics produced very little other than explicit propaganda for the communist regime and elaborated its ideology by using and abusing their academic and professional authority. Ideological and political servility among scholars was enforced in many cases, transforming them into totalized subjects with virtually no scientific courage. Definitely, some carried outright research for communist purposes in ways that they would benefit from the communist revolutionizing machine or contribute to it.

The instrumental activism of the practitioners of people's culture scholars was expected to contribute to an extremely important process of aesthetic and cultural cleansing in the struggle against the reactionary vestiges of the past and the alien manifestations of foreign influence. In this culturalist project of political folklorism, the exclusionist socio-class understanding of the "people" may be considered to have paralleled more specifically ethno-religious and ethno-racial categories of the "people" that in addition to Soviet Stalinism, as shown in more detail elsewhere (Doja, 2014b), were specifically used in support of such chauvinistically and ideologically charged projects as Italian fascism, German Nazism and Serbian genocidal nationalism.

Because folkloric studies of people's culture are notoriously not interested in the social analysis of power, practice and process, they tend to isolate their subjects in cultural quarantine. On the pretext of efficiency or, more simply, by absence of any genuine cultural and social project, the industry of folklorism as a pseudo-cultural project of reconstruction and manipulation generally reduced identity claims to a set of frozen values. Ultimately, the traditionalist approach deployed in Albanian studies reduced any attempts to explain people's culture into simple claims to identify its real or imagined roots, while the idealized conception of people's culture removed culture from history and from social life. The introverted perspective of identity retreat, focused on one's own nation-state and people's culture, and the ambivalent emotions induced by running away from backwardness which was nevertheless the source of one's identity, favored not only the calculated facttwisting approach but also major social exclusions.

The great revolutionary mission of social sciences in general and people's culture studies in particular was to provide solution to the social issues brought by the socialist evolvement of society. In this process people's culture became an imagined reality referring to an imagined improvement of social life and well-being of an imagined people. That is what provided essentially emotional and irrational forms of identifications and a basis to all forms of exclusion and intolerance. That is also what provided the imagined people's culture its real sense, while offering an oppressive collective unification. Clearly, such a systematic invention of tradition became dangerous in relation to many matters, especially by authorizing actual political manipulation, which finally served to legitimate impatient and intolerant political solutions.

The new vision of people's democracy as a society without internal struggles required a new ideological model that could create a new image of unity and homogeneity. This model was provided by national-socialism, based on the Stalinist conception of people's culture that should be "national in form and socialist in content", and which became a slogan directly promoted by the ruling party. If the principle of nationalism "asserts that political unity and national unity must be congruent" (Gellner, 1983, 11), more than anywhere else in East and Southeast Europe, including Albania, the eventual social

\footnotetext{
${ }^{10}$ Rexhep Ismajli, 'Doreshkrimet Qe Me La Amanet Selman Riza', Shqiperia.com, 15 December 2009, https://www.shqiperia.com/Doreshkrimet-qe-me-laamanet-Selman-Riza.6529/.
} 
units of the socialist polity were to be compact and reasonably homogeneous. In this context, though practitioners have preferred to claim only a kind of salvage operation for the so-called traditional culture, their contribution was combined to a cultural engineering, half descriptive and half normative, which has been brutal and dramatic. In Albania, the implementation of the national-socialist principles of the folkloric people's culture studies may be seen as a direct outcome of many people having to be forcibly assimilated into the Albanian cultural norms of the national-socialist state. Otherwise, to use the new buzzwords that became part of people's culture of the time, they have to be expelled or "rotated" (qarkulluar), stigmatized as "de-classed" (deklasuar) and "people's foe" (armik i popullit), processed with "re-education" (riedukim), relegated to "internal exile" (internim), imprisoned or killed.

In this context, people's culture studies must have mattered in an extreme, sometimes devastating way for many people. The practice and discourse of these studies resonated in the physical application of social engineering and persecution policies by which state power used to apply those transformation agendas that have discredited the values of certain rural/ traditional cultural characteristics of some Albanian people. By giving legitimacy and laying theoretical foundations to the socialist characterization of some people's life and culture as backward and therefore alien and disintegrative, they ultimately justified the policies of class repression, expulsion and resettlement. In this way, more than other social scientific disciplines, people's culture studies seem to have provided theoretical foundation to the communist policy of hegemonic control over the whole population and supported the terrorist repression that Albanian as other communist societies witnessed during socialism.

This history demonstrates not just how the eighteenth-century Romantic legacy became corrupted in a variety of cultural and political ways by twentieth-century professionals as showed in more detail elsewhere (Doja, 2015), but more importantly how easily academic research as a whole can become corrupted and instrumentalized by political interests. Communist politics, party authoritarianism and Stalinist tyranny, all together with exclusive nationalism had their impact on Albanian people's culture studies in different but important ways. Unequivocally, people's culture studies during socialism in Albania, like their counterparts in German Volkskunde and elsewhere (Doja, 2014a, 2014b), must be unhesitatingly indicted as nationalist and communist apologists for oppressive and exclusivist policies. Based on their conservative national and political objectives, they were highly disposed if not even predestined to be used and misused under communist rule as a national science that could systemically stabilize state control. More than anything else, the ways in which the socio-class notion of people's culture and nation's identity was enforced also undermined the cultural roots of national conscience with implications to national cohesiveness that left a long lasting imprint in the social construction of Albanian society. That is why the story must be told of a profession which proclivities towards national-socialist ideology and conservative thought went along with the communist takeover. Full acknowledgment of this fact can become another instance of the Albanian postcommunist willingness to come to terms with the communist past.

\section{Conclusion}

The way people's culture studies have functioned to explore and construct a particular socio-class division of the "people", all together with a vision of exclusivist self against the forcibly alienation of the backward other, show that this approach facilitated the subversion of scholarship into a political instrument of communist propaganda, cultural hegemony and state control that ultimately destabilized the Albanian social fabric. In this context, this article aimed to highlight how totalitarian regimes employ knowledge production and culture manipulation for their own hegemonic ends, in particular how the social sciences are mobilized to assure regime longevity by legitimating repressive policies and framing a rationale for the persecution of some "culturally retarded" members of society in the name of the people's nation and people's ways of life. A new general contribution to theoretical knowledge is suggested, one that is obtained by the examination of processes of knowledge production and political control in Albania during communism to justify communist policies of cultural hegemony, especially by means of a new perspective on the ideological engineering of folklorism and on the manipulation of people's culture. In this way, the arguments and the insights obtained from the critical assessment of the political and ideological context into which the available Albanian scholarship developed can be useful to appreciate comparative uses and misuses of native studies throughout nationalist and communist contexts in Eastern Europe and socalled socialist societies.

If social scientific approach is to emerge and persist as a viable field in Albania, as elsewhere, it needs to attend more carefully to its own social reproduction. The task is therefore not simply to summarize previous and established insights and opinions, but rather to question those previously established opinions and practices that today seem to be condemnable, though still at work in Albanian politics of knowledge. Ultimately, we need to consider how to engage constructively with the past in ways that may develop a vision for a renewed approach within Albanian studies from the perspective of those critical and internationally oriented positions that we need to strengthen and promote today.

The pervasive reifying effects as the essentializing discourses that characterize Albanian studies of people's culture certainly appear unusual and difficult to grasp, if one schematically employs traditional categories developed in current scholarship dealing with this question. In turn, an articulate analysis of the main intellectual traditions and their impact, linked to a careful examination of the historical contextualization in ideological perspective, is likely to produce a more sophisticated understanding of the cultural particularism of Albanian studies during socialism. While analyzing the historical, cultural, and political terrain in which certain influential ideas and practices in Albanian studies of people's culture emerged, the aim of this article was to frame the argument in such a way as to focus on a critical reassessment of different strands of 
scholarship and take into account the close association of the development of Albanian studies within the shifting contexts and ideologies in communist Albania.

In methodological terms, we tried to engage with a comparative analysis of ideas and practices rather than with a search for positive literal proof. The critical approach advocated here might not be exhaustive, but definitely positioned and selective, while certainly a number of questions that remain open will require complementary efforts of historical research. However, if this article has managed to provoke at the very least a non-stereotyped discussion throughout a set of reflections on the development of Albanian studies in communist Albania, it merely offers itself as one among several possible alternatives. We hope it will encourage further debate, deeper enquiries, and thorough reflection, which can suggest different explanations. Even though it might perhaps justifiably attract attention to self-criticism, it may hopefully stimulate and enrich a debate that could contribute much to the already critical research on historical and current modernization. Ultimately, the conceptual aspects of this situation not only show how to deal with an extant social structural problem of knowledge production but may also have important theoretical and methodological implications beyond those of the specific problems addressed in this article.

\section{Acknowledgment}

We benefited greatly from the presentations, discussions, comments and encouragements of all participants, as well as from numerous friends and colleagues who have read parts of this paper at various stages and have helped to improve our argument: Chris Hann, Christian Giordano, Andre Gingrich, Klaus Roth, Christian Voss, Stephane Voell, Alexandar Boskovic, Pamela Bollinger, Vesna Godina, Evthymios Papataxiarchis, Jurij Fikfak, Rajko Mursic, Robert Gary Minnich. We are also very grateful to the anonymous reviewers for their insightful comments and recommendations.

\section{References}

Abazi, Enika, 2010. Tranzicioni i munguar në shkencat sociale shqiptare: deskriptivizmi empiriko-historicist kundrejt qasjes kritiko-analitike. Polis 9, 63-76.

Abazi, Enika, 2011. Tranzicioni dhe shkencat sociale shqiptare: një qasje kritike. Politiks 2, 209-215.

Bardhoshi, Nebi, 2009. Teoria etnografike e Rrok Zojzit mbi të drejtën kanunore: Një vështrim kritik. Kult. Pop. 28 (1-2), 69-94.

Bausinger, Herman, 1993. Volkskunde ou l'ethnologie allemande: de la recherche sur l'antiquité à l'analyse culturelle. Éditions de la Maison des sciences de l'homme, Paris.

Blumi, Isa, 1999. Hoxha's class war: the cultural revolution and state reformation 1961-1971. East Eur. Q. 33 (3), $303-326$.

Bogdani, Ramazan, 1977. Tendances d'innovation du folklore choréographique albanais aux conditions du développement de la société socialiste. In: Conférence Nationale des Études Ethnographiques, 28-30 juin 1976. Tirana, Académie des Sciences, pp. 583-589.

Boskovic, Aleksandar, Hann, Chris (Eds.), 2013. The Anthropological Field on the Margins of Europe, 1945-1991. LIT-Verlag, Berlin/Münster.

Bromley, Yulian, Kozlov, Viktor, 1989. The theory of ethnos and ethnic processes in Soviet social science. Comp. Stud. Soc. Hist. 31 (3), $425-438$.

Buda, Aleks, 1977. Etnografia shqiptare dhe disa probleme të saj - L'ethnographie albanaise et ses problèmes. In: Konferenca Kombëtare e Studimeve Etnografike - Conférence Nationale des Études Ethnographiques 28-30 juin 1976. Tirana, Académie des Sciences, pp. 15-35 [Fr. 19-43].

Cabanes, Pierre, 2004. Archéologie et identité nationale en Albanie au XXe siècle. Dialogues d'Histoire Ancienne 30 (1), 115 -122.

Chirot, Daniel (Ed.), 1991. The Crisis of Leninism and the Decline of the Left: the Revolutions of 1989. University of Washington Press, Seattle.

Dalipaj, Gerda, 2012. Domesticating the domestic: the house in Albanian ethnography during the communist regime. Annu. Yearb. Albanian Hist. Anthropol. Stud. 2, 9-38.

Doja, Albert, 1998. Évolution et folklorisation des traditions culturelles. East Eur. Q. 32 (1), 95-126.

Doja, Albert, 2013a. Folkloric archaism and cultural manipulation in Albania under socialism. In: Boskovic, Aleksandar, Hann, Chris (Eds.), The Anthropological Field on the Margins of Europe, 1945-1991, pp. 153-174. LIT-Verlag, Berlin/Münster.

Doja, Albert, 2013b. Invitation au terrain: Mémoire personnel de la construction du projet socio-anthropologique. Peter Lang, Bruxelles.

Doja, Albert, 2014a. The Beautiful Blue danube and the Accursed Black mountain Wreath: German and Austrian Kulturpolitik of knowledge on Southeast Europe and Albania. Soz. Welt Z. für sozialwissenschaftliche Forsch. Prax. 65 (3), 317-343.

Doja, Albert, 2014b. From the German-speaking point of view: unholy Empire, Balkanism, and the culture circle particularism of Albanian studies. Critique Anthropol. 34 (3), 290-326.

Doja, Albert, 2015. From the native point of view: an insider/outsider perspective on folkloric archaism and modern anthropology in Albania. Hist. Hum. Sci. 28 (4), 44-75.

Dojaka, Abaz, 1975. Veshjet popullore dhe ansamblet folklorike. In: Simpozium për problemet e Festivalit Folklorik Kombëtar të Gjirokastrës (Tetor 1973), Tirana, pp. 146-151.

Dojaka, Abaz, Gjergji, Andromaqi, 1969. Rezultatet e punës në fushën e etnografisë gjatë 25 vjetëve. Stud. Hist. 6 (4), $107-119$.

Feder, Kenneth L., 2011. Frauds, Myths, and Mysteries: Science and Pseudoscience in Archaeology, seventh ed. McGraw-Hill, New York.

Fico, Agron, 1979. Partia në këngën e popullit. 8-Nëntori, Tirana.

Gellner, Ernest, 1983. Nations and Nationalism. Cornell University Press, Ithaca.

Gjergji, Andromaqi, 1963. Provë për një studim etnografik në kooperativën bujqësore Shkëndia në rrethin e Korçës. Etnogr. Shqip. 2, 81-109.

Gjergji, Andromaqi, 1965. Ndryshime në mënyrën e jetesës së fshatarësisë kooperativiste. In: Konferenca e Parë e Studimeve Albanologjike, 15-21 Nëntor 1962. Tirana, pp. 626-632.

Gjergji, Andromaqi, 1968. Ndryshime në pozitën familjare të gruas fshatare (sipas materialeve të mbledhura në kooperativën Çlirimi në fshatin Pojan të rrethit të Korçës). Stud. Hist. 5 (4), 89-99.

Gjergji, Andromaqi, 1973. Disa probleme në lidhje me zhvillimin e familjes së sotme fshatare. Stud. Hist. 10 (4), $73-86$.

Gjergji, Andromaqi, 1975. Tradita dhe evoluimi në veshjet popullore. In: Simpozium për problemet e Festivalit Folklorik Kombëtar të Gjirokastrës (Tetor 1973), Tirana, pp. 80-89.

Gjergji, Andromaqi, 1977. Mbi disa kritere të vlerësimit të veshjeve popullore. In: Konferenca Kombëtare e Studimeve Etnografike. Tirana, pp. 397-402.

Gjergji, Andromaqi, 1979. Ndryshimet e mëdha në mënyrën e jetesës në fshat dhe prirjet e zhvillimit në të ardhmen. In: Konferenca Kombëtare për problemet e ndërtimit socialist. Tirana.

Gjergji, Andromaqi, 1981. Raporti midis strukturës së familjes kooperativiste dhe hapësirës së banuar prej saj (në fushën e Korçës). Kult. Pop. 2 (2), $27-37$.

Gjergji, Andromaqi, 1983. Le village en tant que territoire d'habitation et unité sociale. Ethnogr. Albanaise 12.

Gjergji, Andromaqi, 1984. L'ethnographie et le village albanais d'aujourd'hui. Stud. Albanica 21 (2), 95-98.

Gjergji, Andromaqi, 1985. Les transformations du mode vie de la paysannerie contemporaine. Ethnogr. Albanaise 14, 5-34. 
Gjergji, Andromaqi, 1986. Le développement économique et la modification du mode de vie de la campagne. Cult. Pop. Albanaise 6, 57-68.

Gjergji, Andromaqi, 1987. Tradita dhe risi në mënyrën e jetesës në fshat. Kult. Pop. 8 (2), 53-60.

Gjergji, Andromaqi, 2001. Ligjërata për etnologjinë shqiptare (Extra, Tirana).

Gjergji, Andromaqi, 2002. Mënyra e jetesës në shekujt XII-XX (Kotti, Tirana).

Gjergji, Andromaqi, 2006. Arti i zbatuar popullor. Ilar, Tirana.

Hann, Chris, Sarkany, Mihaly, Skalnik, Peter (Eds.), 2005. Studying Peoples in the People's Democracies: socialist era Anthropology in East-Central Europe. LIT-Verlag, Berlin/Münster.

Haxhiu, Fiqri, 1963. Kooperativa blegtorale-bujqësore Asim Zeneli (1947-1959). Etnogr. Shqip. 2, 3-49.

Heller, Mikhail, 1988. Cogs in the Wheel: the Formation of Soviet Man. Knopf, New York.

Herzfeld, Michael, 1982. Ours once More: folklore, Ideology and the Making of Modern Greece. University of Texas Press, Austin.

Hobsbawm, Eric, Ranger, Terence (Eds.), 1983. The Invention of Tradition. Cambridge University Press, Cambridge.

Hofer, Tamas, 1968. Anthropologists and native ethnographers in central european villages: comparative notes on the professional personality of two disciplines. Curr. Anthropol. 9 (4), 311-315.

Hysa, Armanda, 2010. Ethnography in communist Albania: nationalist discourse and relation with history. Hist. Semin. 8, $103-125$.

Hysa, Armanda, 2011. Mbi studimin e qytetit në etnografinë shqiptare të periudhës socialiste. Kult. Pop. 30 (1-2), $163-187$.

Hysa, Armanda, 2013. Albanian ethnography at the margins of history 1947-1991: documenting the nation in historical materialist terms. In: Boskovic, Aleksandar, Hann, Chris (Eds.), The Anthropological Field on the Margins of Europe, 1945-1991. LIT-Verlag, Berlin/Münster, pp. 129-151.

Jones, Polly, 2006. The dilemmas of de-Stalinization: negotiating cultural and social change in the Khrushchev era. Routledge, London/New York.

Kostallari, Androkli, 1969. Mbi shtrirjen e shtresëzimin e së drejtës kanunore në Shqipëri dhe mbi disa çështje që lidhen me studimin e saj e me organizimin e luftës kundër mbeturinave të së vjetrës. In: Disa probleme të studimeve shoqërore. Naim-Frasheri, Tirana, pp. 120-131.

Kruta, Beniamin, 1977. Rapport entre l'authenticité et le caractère de spectacle dans le folklore contemporain. In: Conférence Nationale des Études Ethnographiques, 28-30 juin 1976. Tirana, Académie des Sciences, pp. 573-582.

Kruta, Beniamin, Shituni, Spiro, Xhagolli, Agron (Eds.), 1986. Enver Hoxha tungjatjeta: Këngë e melodi. Institut de Culture Populaire, Tirana.

Lelaj, Olsi, 2011. Një analizë kritike e studimeve etnografike shqiptare mbi shoqërinë e real socializmit në Shqipëri. Kult. Pop. 30 (1-2), 199-224.

Luari, Nexhmedin, 1977. Kolektivizimi i bujqësisë: faktor vendimtar për shndërrimet në psikologjinë e fshatarëve. In: Konferenca Kombëtare e Studimeve Etnografike, 28-30 qershor 1976. Tirana, Akademia Shkencave, pp. 295-299.

Martucci, Donato, Genesin, Monica, 2012. Gjuha dhe kultura shqipe në veprimtarinë e Qendrës së Studimeve për Shqipërinë (Centro Studi per l'Albania, 1939-1944). In: Ismajli, Rexhep (Ed.), Shqipja dhe gjuhët e Ballkanit - Albanian and Balkan Languages. ASHAK, Prishtina, pp. 595 -607.

Mehilli, Elidor, 2011. Defying de-stalinization: Albania's 1956. J. Cold War Stud. 13 (4), 4-56.

Mihailescu, Vintila, Iliev, Ilia, Naumovic, Slobodan (Eds.), 2008. Studying Peoples in the People's Democracies II: Socialist era Anthropology in South-East Europe. LIT-Verlag, Münster/Berlin.

Muka, Ali, 2007. Ndërtimet tradicionale fshatare (shek. XVIII-XX): Monografi etnologjike. Akademia e Shkencave, Tirana.

Naumovic, Slobodan, 1998. Romanticists or double insiders? an essay on the origins of ideologised discourses in Balkan ethnology. Ethnol. Balk. 2, $101-120$.

Nikolla, Albert P., 2011. L'uomo nuovo albanese: Tra morale comunista e crisi della transizione. Bonanno, Roma.

Noack, Karoline, Krause, Martina, 2005. Ethnographie as a unified anthropological science in the German democratic republic. In: Hann, Chris, Sarkany, Mihaly, Skalnik, Peter (Eds.), Studying Peoples in the People's Democracies: socialist era Anthropology in East-Central Europe. LIT-Verlag, Berlin/Münster, pp. 25-54.

Osiatynski, Wiktor, 1991. Revolutions in eastern Europe. Univ. Chic. Law Rev. 58 (2), 823-858.

Panajoti, Jorgo, Kruta, Beniamin, 1986. Le folklore albanais à l'époque du Parti communiste. Cult. Pop. Albanaise 6.

Qarri, Nimete, 1976. Ndryshime në mënyrën e jetesës së fshatarësisë kooperativiste në Lekaj. Stud. Hist. 13 (4), $187-192$.

Roth, Klaus, 1998. Folklore and nationalism: the German example and its implications for the Balkans. Ethnol. Balk. 2, 69-79.

Sako, Zihni, 1975. Festivali Folklorik Kombëtar i Gjirokastrës 1973: Etapë e rëndësishme e artit dhe e kulturës sonë popullore socialiste. In: Simpozium për problemet e Festivalit Folklorik Kombëtar të Gjirokastrës (Tetor 1973), Tirana.

Schmitt, Oliver J., 2005. Genosse Aleks und seine Partei, oder: Zur Politik und Geschichtswissenschaft im kommunistischen Albanien (1945-1991). In: Krzoska, Markus, Maner, Hans-Christian (Eds.), Beruf und Berufung: Geschichtswissenschaft und Nationsbildung in Ostmittel- und Südosteuropa im 19. und 20. Jahrhundert. LIT-Verlag, Münster, pp. 143-166.

Schwandner-Sievers, Stephanie, 2009. Jungfrauen und Elefanten im Porzellanladen: Zur internationaler Herausforderung der albanischen Ethnologie im Postsozialismus. In: Schmitt, Oliver J., Frantz, Eva (Eds.), Albanische Geschichte: Stand und Perspektiven der Forschung. Oldenbourg, München, pp. $187-214$.

Shanks, Michael, Tilley, Christopher Y., 1992. Re-constructing archaeology: theory and Practice, second ed. Routledge, London.

Shituni, Spiro, 1988. Cilësia si problem themelor i artit muzikor popullor. Kult. Pop. 9, 25-38.

Shituni, Spiro, 1989. Art origjinal, i pasur dhe i gjallësishëm: Muzika popullore në Festivalin folklorik kombëtar 1988. Kult. Pop. 10 (1), 13-22.

Shituni, Spiro, Daja, Ferial, Pano, Natasha (Eds.), 1986. Këngë e melodi nga festivalet folklorike. Institut de Culture Populaire, Tirana.

Shkurti, Spiro, 1976. Vështrim etnografik mbi zonën e Vurgut. Etnogr. Shqip. 8, 111-158.

Shkurti, Spiro, 2004. Tradita bujqësore ndër shqiptarë. Akademia e Shkencave, Tirana.

Tarifa, Fatos, 1996. Neither bourgeois nor communist science: sociology in communist and post-communist Albania. Communist Post-Communist Stud. 29 (1), 103-113.

Tirta, Mark, 1982. Vështrim rreth popullsisë së ardhur në vendbanimet e krijuara pas Çlirimit në mjedise bujqësore. Etnogr. Shqip. 13, 5-29.

Tirta, Mark, 1985. Reforma agrare dhe lëvizjet e popullsisë fshatare. Kult. Pop. 6 (2), 43-62.

Tirta, Mark, 1986. Les mouvements contemporains de la population et le développement des villes albanaises. Ethnogr. Albanaise $15,5-34$.

Tirta, Mark, 1987. Lëvizje migruese të brendshme të popullsisë. Etnogr. Shqip. 16, 33-64.

Tirta, Mark, 1999. Migrime të Shqiptarëve: të brendshme dhe jashtë atdheut. Akademia e Shkencave, Tirana.

Tirta, Mark, 2003. Etnologjia e shqiptarëve. Geer, Tirana.

Tirta, Mark, 2004. Mitologjia ndër Shqiptarë. Akademia e Shkencave, Tirana.

Tirta, Mark, 2007. Panteoni e simbolika: doke e kode në etnokulturën shqiptare. Ilar, Tirana.

Uçi, Alfred, 1969. Mbi disa aspekte kryesore metodologjike për studimin e problemit të familjes. In: Disa probleme të studimeve shoqërore. Naim-Frasheri, Tirana, pp. $162-170$.

Uçi, Alfred, 1976. Vendi i artit popullor në kulturën artistike socialiste. Stud. Filol. 13 (3), 13-32.

Uçi, Alfred (Ed.), 1980. Probleme të zhvillimit të folklorit bashkëkohor [Issues of the evolution of contemporary folklore]. Akademia e Shkencave, Tirana.

Uçi, Alfred, 1981. Le Festival Folklorique National de 1978: questions actuelles des sciences ethnographiques et folkloriques. Cult. Pop. Albanaise 1, 7-24.

Uçi, Alfred, 1982. Mitologjia, Folklori, Letërsia (Naim-Frashëri, Tirana).

Uçi, Alfred, 1984. La Culture populaire traditionnelle et ses fonctions ethniques. Cult. Pop. Albanaise 4, 19-44.

Uçi, Alfred, 1989. Le folklore actuel avec les nouvelles splendeurs de notre temps. Cult. Pop. Albanaise 9, 9-13.

Uçi, Alfred, 1997. Për një rivlerësim kritik të përvojës së zhvillimit të kulturës popullore. Kult. Pop. 18 (1-2), 173-186.

Uçi, Alfred, 2007. Estetika e Folklorit. Akademia e Shkencave, Tirana.

Uçi, Alfred, et al. (Eds.), 1985. Enver Hoxha në këngët e popullit. Akademia e Shkencave, Instituti i Kulturës Popullore, Tirana.

Ulqini, Kahreman, 2003. Struktura e shoqërisë tradicionale shqiptare (Idromeno, Shkodra).

Valtchinova, Galia, 2004. Folkloristic, ethnography, or anthropology: Bulgarian ethnology at the crossroads. J. Soc. Anthropol. Eur. 4 (2), 2-18.

Vehbiu, Ardian, 2009. Shqipja totalitare: tipare të ligjërimit publik në Shqipërinë e viteve 1945-1990 (Çabej, Tirana). 
Voell, Stephane, 2011. The Kanun in the ethnographic self-description: research into Albanian traditional law during socialism. In: Brunnbauer, Ulf, Kraft, Claudia, Schulze-Wessel, Martin (Eds.), Sociology and Ethnography in East-Central and South-East Europe: Scientific Self-description in State Socialist Countries. Oldenbourg, München.

Wallace, Anthony F.C., 1956. Revitalization movements. AA 58 (2), 264-281.

Xhagolli, Agron (Ed.), 1983. Truall me këngë (Tirana).

Xhagolli, Agron (Ed.), 1988. Festivali folklorik kombëtar (Tirana).

Xhagolli, Agron, 1997. Arritje dhe probleme të folkloristikës dhe të etnologjisë shqiptare. Kult. Pop. 18 (1-2), 3-15.

Xholi, Zija, 1977. La révolution culturelle socialiste et la culture populaire nationale. In: Conférence Nationale des Études Ethnographiques, 28-30 juin 1976. Tirana, Académie des Sciences, pp. 65-85.

Yzeiri, Ilir, 2013. Semiopragmatika e realizmit socialist (1944-1949). Onufri, Tirana.

Zojzi, Rrok, 1959. Etnografia shqiptare dhe veprimtaria shkencore e zhvillueme në këtë fushë. Bul. i Univ. Shtetëror të Tiranës Ser. Shk. Shoqërore (4), 153-161.

Zojzi, Rrok, 1975. Për një trajtim shkencor të veshjes popullore. In: Simpozium për problemet e Festivalit Folklorik Kombëtar të Gjirokastrës (Tetor 1973), Tirana, pp. 52-60. 